(C) A.M. Егорычев, Е.В. Казакова

DOI: http://doi.org/10.15350/2409-7616.2021.3.10

УДК 37.06

\author{
ДЕТИ МИГРАНТОВ (УРОВЕНЬ НАЧАЛЬНОГО ОБРАЗОВАНИЯ) \\ И ХАРАКТЕРНЫЕ ПРОБЛЕМЫ ИХ АДАПТАЦИИ \\ В РУССКОЯЗЫЧНОЙ ШКОЛЕ \\ А.М. Егорычев, Е.В. Казакова
}

Егорычев Александр Михайлович, доктор философских наук, профессор, Российский государственный социальный университет; главный научный сотрудник, Институт демографических исследований РАН; почетный профессор Новосибирского государственного педагогического университета, Москва, Россия. РИНЦ SРIN-код: 2557-4037 / ORCID ID: orcid.org/ 0000-0002-7497-4508. E-mail: chelovekcap@mail.ru

Казакова Елена Владимировна, доцент кафедры педагогики и методики начального образования, Новосибирский государственный педагогический университет, Новосибирск, Россия. РИНЦ SPIN-код: 8711-3685 / ORCID ID: orcid.org/ 0000-0003-0158-7264. E-mail: elekta@nxt.ru

\begin{abstract}
Аннотация. B статье представлены результаты теоретико-аналитического анализа проблемы адаптации детей-мигрантов к новым для них условиям русскоязычной школьы. Практика начальной школь, результаты отечественных психологических, педагогических, сочиально-педагогических исследований вопросов адаптаџии младиих школьников - детей мигрантов к русскоязычной школе свидетельствуют об актуальности данной проблемы, как для самих иноэтничных младших школьников, так и для всего российского педагогического сообщества, в изелом для российского государства. Цель настоящей статьи - выяснить сложившееся в отечественной научной литературе отношение к проблеме адаптации детей мигрантов к русскоязычной школе. Основные задачи исследования состояли в том, чтобы на основе анализа научной литературы, включая наблюдения за процессом обучения и воспитания младших школьников - детей мигрантов, а также обязательное обсуждение вопросов, касающихся настоящей проблемы с учителями начальных классов, выявить и описать существующие проблемы адаптации иноязычных учашихся к русскоязычной школе, выработать авторскую позицию по их решению. Результать проведенного исследования показали, что проблема социальной адаптаџии детей мигрантов к новой для них школьной среде, с одной сторонь - сложная $u$ противоречивая, с другой - вполне решаемая при обязательном согласовании действий всех участников образовательного прочесса (родителей и их детей, педагогического коллектива школьи, других заинтересованных лии и организаций).
\end{abstract}


Ключевые слова: дети мигрантов, иноэтничные младшие школьники, начальная школа, адаптация, проблемы адаптациии младших школьников.

UDC 37.06

\title{
CHILDREN OF MIGRANTS (PRIMARY EDUCATION LEVEL) AND CHARACTERISTIC PROBLEMS OF THEIR ADAPTATION IN RUSSIAN SCHOOL
}

A.M. Egorychev, E.V. Kazakova

\author{
Alexander M. Egorychev, \\ Doctor of Philosophy, Professor of the Russian State Social \\ University; Chief Researcher, Institute for Demographic Research, \\ Russian Academy of Sciences, Moscow, Russian Federation. \\ ORCID ID: orcid.org/ 0000-0002-7497-4508 \\ E-mail: chelovekcap@mail.ru \\ Elena V. Kazakova, \\ Docent, Department of Pedagogy and Methods \\ of Primary Education, Novosibirsk State Pedagogical \\ University, Novosibirsk, Russian Federation. \\ ORCID ID: orcid.org/0000-0003-0158-7264 \\ E-mail: elekta@nxt.ru
}

\begin{abstract}
The article presents the results of a theoretical and analytical analysis of the problem of adaptation of migrant children to the new conditions of the Russian-language school. The practice of elementary school, the results of domestic psychological, pedagogical, socio-pedagogical studies of the adaptation of junior schoolchildren - children of migrants to the Russian-speaking school indicate the relevance of this problem, both for the foreign-ethnic junior schoolchildren themselves, and for the entire Russian pedagogical community, as a whole for the Russian state ... The purpose of this article is to clarify the attitude of the Russian scientific literature to the problem of adaptation of migrant children to the Russian-language school. The main objectives of the study were to identify and describe the existing problems of adaptation of foreign language students to Russian-speaking school, to develop an author's position on their solution. The results of the study showed that the problem of social adaptation of migrant children to a new school environment for them, on the one hand, is complex and contradictory, on the other hand, it can be completely solved with the obligatory coordination of the actions of all participants in the educational process (parents and their children, teachers, etc. school educators, other interested persons and organizations).
\end{abstract}

Keywords: children of migrants, ethnic minority schoolchildren, primary school, adaptation, problems of adaptation of younger schoolchildren. 
Обоснование проблемы исследования. Проблемы миграции, связанные с распадом СССР, затронули разные сферы деятельности человека, в том числе и образование. В общеобразовательных школах Российской Федерации с каждым годом растет число детей иностранных граждан (мигрантов), по разным причинам приезжающих в нашу страну из бывших союзных республик.

Мигрант - лицо, переселяющееся на постоянное или временное новое место проживания. Большинство мигрантов испытывает огромные трудности на неродной территории, зачастую связанные с проблемами коммуникации, ведь многие слабо или вовсе не владеют русским языком. Особенно страдают в данной ситуации дети: им трудно общаться с учителями, сверстниками, полноценно учиться и развиваться, в целом успешно социализироваться в окружающей их среде.

В России опыт изучения проблем детей мигрантов накоплен учеными Москвы, СанктПетербурга, Екатеринбурга, Ставрополья и других крупных городов и регионов России.

В становлении и развитии российской мигрантской педагогики и психологии важную роль играют исследования отечественных ученых - Г.У. Солдатовой, Е.В. Бондаревской, В.С. Кукушина, В.В. Константинова, Т.Г. Стефаненко и мн. др.

Проблемам адаптации и интеграции детей из семей мигрантов посвящены исследования ученых Е.А. Омельченко, Г.Е. Зборовского, В.П. Засыпкина, Е.А. Шуклиной, Л.Н. Зимаковой, Т.В. Куприной, Е.А. Трушкиной, С.Н. Кириченко и др.

Дети уровня начального образования из семей мигрантов в русскоязычной школе сталкиваются с различными трудностями: языковыми, психологическими, социальными, культурными (социокультурными), учебными.

В целом, можно говорить о том, что проблема адаптации детей мигрантов к новой социокультурной среде русскоязычной школы сегодня является актуальной, важной и социально востребованной. Её позитивное решение затрагивает многие стороны российской реальности (политической, социальной, образовательной, воспитательной, межнациональной, культурной, коммуникативной, пр.)

Теоретико-методологические основы исследования. Настоящее исследование носит аналитико-теоретический характер. В нем использовались следующие методы: теоретические (анализ, синтез, сравнение, сопоставление, моделирование, обобщение); эмпирические (наблюдение, беседы, интервью, фокус-группы). В исследовании мы опирались на научные труды известных отечественных ученых, занимающихся данной проблематикой (Е.В. Бондаревская, А.М. Егорычев, В.П. Засыпкин, Г.Е. Зборовский, Л.Н. Зимакова, С.Н. Кириченко, В.В. Константинов, В.С. Кукушин, Т.В. Куприна, А.Я. Макаров, Е.А. Омельченко, Т.К. Ростовская, Г.У. Солдатова, Т.Г. Стефаненко, Е.А. Трушкина, Е.А. Шуклина, др.). Предметом исследования выступает адаптация детей мигрантов в русскоязычной школе. Ключевыми методологическими понятиями являются: «дети мигрантов», «адаптация», «адаптация детей мигрантов», «социализация», «социализация детей мигрантов», «интеграция», «интеграция детей мигрантов».

Обсуждение результатов исследования. В отечественной научной литературе мы встречаем различные названия данной категории детей: дети мигрантов (реже детимигранты), дети из семей мигрантов, иностранные граждане, дети иностранных граждан, иноэтничные дети, иноязычные дети - все эти термины являются точными синонимами. Речь идет о детях, которые вместе с родителями мигрировали в Россию из стран ближнего зарубежья и родным языком которых не является государственный язык Российской Федерации.

С точки зрения социологии, антропологии, исследователи Е.А. Омельченко, В.П. Засыпкин, Г.Е. Зборовский, Е.А. Шуклина, А.Я. Макаров, определяют сущность понятия «дети мигрантов» как «особую социальную общность, находящуюся во взаимодействии с 
родителями, родственниками, сверстниками (в основном русскоязычными) и учителями» $[20$, c. 251$]$.

Основаниями для объединения данной категории детей в «особую общность» является целый комплекс признаков (семейные, социокультурные, возрастные, этнические, религиозные, территориальные, др.). Так, В.П. Засыпкин, Г.Е. Зборовский, Е.А. Шуклина дают следующее определение детям мигрантов: «Реально существующая, эмпирически фиксируемая, относительно единая совокупность (взаимосвязь) детей (в возрасте до 18 лет), объединенных по социокультурным, возрастным, этническим, отчасти территориальным и религиозным основаниям» [4, с. 12]. Как указывают ученые, данная «общность характеризуется рядом образующих признаков: относительной целостностью, осознанием детьми своей принадлежности к общности (идентификацией и самоидентификацией с ней), схожими условиями жизни и деятельности, наличием определенных пространственновременных полей бытия, реализацией функций поведения на основе обладания и использования различных ресурсов» [4, с. 12].

С позиции социальной педагогики и психологии, определение сущности и содержания понятия «дети мигрантов» базируется на несколько иных основаниях: «это дети с особыми образовательными потребностями, нуждающиеся в своевременном содействии, помощи, поддержке, сопровождении» [23, с. 184].

Помощь, поддержка и сопровождение могут быть самого разного вида: психологопедагогическая, социально-педагогическая, социокультурная, этнокультурная, иная, в зависимости от индивидуальных потребностей и возможностей ребенка, сложившейся ситуации. Социально-педагогическая практика российской школы свидетельствует, прежде всего, о необходимости «языковой поддержки» детей иностранных граждан. Большая часть детей нуждается в педагогической помощи при освоении русского языка не только в первый год обучения в иноязычном учебном заведении и не столько в рамках школьной учебной дисциплины «Русский язык», сколько на личностном и бытовом уровне. Иноязычные дети испытывают сложности в коммуникации со сверстниками, учителями, окружающими людьми чаще всего из-за слабого владения языком принимающей стороны.

Термин «адаптация» в широком смысле понимается как приспособление к изменяющимся внешним и внутренним условиям. С точки зрения психологии, адаптация это приспособление личности к существованию в обществе в соответствии с требованиями этого общества и собственными интересами, мотивами, потребностями личности. Под социальной адаптацией Л.В. Мардахаев понимает «приспособленность человека к условиям социальной среды, социуму, что создает предпосылки для его наиболее полного, естественного самопроявления» [18, с. 122].

Таким образом, «адаптация как процесс представляет собой, с одной стороны, естественное приспособление свойств и качеств человека к новым для него условиям социокультурной среды жизнедеятельности (классу, группе ...), а с другой, - накопление опыта приспособления к новому, с третьей, - развитие адаптационных возможностей (адаптивности)» [18, с. 122-123]. По мнению Л.В. Мардахаева, «адаптивность - качество личности, заключающееся в предрасположенности к приспособлению в новой ситуации и определяющее... перспективы ее приспособления и наиболее полного проявления в условиях новой обстановки. В учебе оно обозначает способность обучаемого к гибкой переориентации на содержание, формы и методы обучения» [18, с. 123].

Неумение человека приспосабливаться к новой обстановке, неразвитость его адаптационных возможностей - неадаптивность - приводит к дезадаптащии - нарушенной, искаженной адаптации, которая проявляется в трудностях общения и деятельности.

Еще одно понятие, сопряженное с понятиями «адаптация», «адаптивность», адаптированность. Адаптированность - это результат процесса адаптации, свидетельствующий о том, что человек приспособился к новым условиям среды (работе, 
учебе и т.д.). Факторами адаптированности человека можно считать комфортные для личности условия жизнедеятельности, обучения, располагающие к еe успешному самопроявлению, развитию, социализации, проявлению творческих способностей и, самое главное, - позволяющие успешно интегрироваться в российское общество.

Засыпкин В.П., Г.Е. Зборовский, Е.А. Шуклина следующим образом определяют учебную, социально-психологическую, культурную проблемы адаптации детей мигрантов: «Учебная адаптация означает усвоение предписываемых норм и ценностей школьного поведения, а также включение подростков в учебную и воспитательную деятельность, их участие во внеклассной работе. Социально-психологическая адаптация отражает процессы межличностного взаимодействия с одноклассниками, широту и глубину складывающихся внутри класса взаимосвязей, а также их гармоничность, удовлетворенность ими. Культурная адаптация выступает как развитие творческих способностей учащихся, знание ими истории и современной жизни принимающего общества, готовность следовать предписываемым ... культурным образцам. Другая сторона этого процесса - включение в местную подростковую и молодежную культуру. Оно происходит на фоне трансформации этнической и языковой среды мигрантов» [6, с. 37].

Е.А. Омельченко отмечает отсутствие единых критериев - показателей адаптации и интеграции иноэтничных мигрантов в принимающее общество. Исследователь, анализируя определения понятия «адаптация мигрантов», предлагаемые зарубежными, российскими учеными, выясняет, что единого подхода, а также определения данного понятия нет, в разных исследованиях и «действующих нормативных документах и законопроектах понятия ассимиляции, приспособления, поглощения, адаптации, объединения, аккультурации, интеграции используются весьма противоречиво и непоследовательно» [19, с. 271].

В российских законодательных документах также нет единого подхода к определению сущности и содержания данных понятий. В двух определяющих миграционную политику государственных документах - «Концепции государственной миграционной политики РФ до 2025 г.» и в «Стратегии государственной национальной политики РФ на период до 2025 г.» «устойчивое сочетание «адаптация и интеграция мигрантов» фигурирует и достаточно активно используется», но, как отмечает Е.А. Омельченко, «внятного определения ему не дается» [19, с. 269].

Е.А. Омельченко также указывает, что, в отличие от определения данного понятия в законопроекте «О социальной и культурной адаптации и интеграции иностранных граждан в Российской Федерации» 2013 г., где адаптация определена как «совокупность усилий институтов гражданского общества, органов государственной власти и иностранных граждан», в законопроекте 2017 г. адаптация представлена как однонаправленный процесс (указывается, что усилия предпринимаются только самими мигрантами). Разница в понятиях адаптации и интеграции в законодательных документах определяется временем пребывания иностранных граждан на российской территории.

Адаптация - это, прежде всего, процесс, связанный с приспособлением человека к новой среде своего жизнеосуществления. Социальная интеграция, - пишет Е.А. Омельченко, - «это сложный процесс, предполагающий успешное включение человека в общество. Под термином «интеграция» предлагается понимать одновременное изменение мигрантов и общества, обеспечивающее полноценное включение иммигрантов в социокультурную структуру российского общества и определенное изменение самой социокультурной структуры под воздействием этих процессов» [19, с. 271-272].

Представленные Е.А. Омельченко определения сущности понятий «адаптация» и «интеграция» вполне применительны к категориям детей из семей мигрантов с учетом языкового, культурного, социального и психологического аспектов.

Е.М. Погребицкая (2015), Т.В. Куприна (2017) подчеркивают важность проблем языковой и социокультурной адаптации «в связи со сложностью вовлечения детей мигрантов 
в различные виды образовательной, культурно-досуговой и социальной деятельности из-за языкового и социокультурного барьера» [15, с. 68].

Авторские концептуальные подходы к решению проблемы. Для успешной адаптации иноэтничных детей в русскоязычной школе, по мнению многих исследователей проблем детей мигрантов, школьных учителей, руководителей общеобразовательных учреждений, а также по личным наблюдениям авторов данной статьи, необходимо комплексно подходить к качественному решению данного вопроса. В образовательном учреждении (в нашем случае это уровень начальной школы) работу следует организовывать в нескольких направлениях, которые имеют внутреннюю взаимосвязь:

- языковая подготовка;

- психологическое и социокультурное сопровождение;

- социально-педагогическая помощь и поддержка.

Нужно также не забывать об общих учебных проблемах детей мигрантов, возникающих из-за незнания или слабого знания русского языка, существующих комплексах поддержки в данном направлении.

Необходимо отметить, что дети из семей мигрантов, как правило, владеют русским языком в разной степени: одни говорят свободно, чаще с акцентом, другие с грамматическими ошибками, третьи практически не владеют языком. Это зависит от целого комплекса причин.

При общении с иноэтничными детьми в начальной школе было отмечено следующее:

- дети-билингвы быстрее идут на контакт: они одинаково хорошо владеют как своим родным языком, так и русским. Билингвы свободно или почти свободно вступают в диалог: на русском языке рассказывают о себе, семье, с удовольствием отвечают на вопросы;

- другие - большей частью инофоны (это дети, слабо или вовсе не владеющие русским языком) - при знакомстве в активный диалог не вступают, в лучшем случае отвечают на элементарные вопросы и просьбы: как тебя зовут? Твоя фамилия? В каком классе ты учишься? Напиши свое имя на доске. Поставь в нем ударение.

Некоторые дети не отвечают на вопросы и не выполняют задания, но чаще всего с такими элементарными для младших школьников задачами большинство инофонов справляется. Инофоны говорят тихо, невнятно, заменяя гласные, твердые и мягкие звуки. Причиной тому, очевидно, неуверенность, основанная на слабом владении русским языком.

Именно с детьми-инофонами при обучении их русскому языку возникает масса трудностей. В большинстве своем родители ребенка-инофона не говорят на государственном языке страны проживания или же знают тот минимум, который необходим для их жизнедеятельности. В данном случае роль учителя в образовании ребенка-инофона становится как никогда важной и ответственной. Педагог начальной школы должен незамедлительно начать занятия с детьми-инофонами с самого начала учебного года.

В общеобразовательных школах российских городов все больше появляется детейинофонов и билингвов. Процесс их обучения и воспитания следует организовывать поособому. Как и русскоязычные дети, они поступают в общеобразовательную школу с государственным русским языком и сразу же сталкиваются с множеством проблем учебных, воспитательных, коммуникативных, социокультурных, психологических, организационных, др.

Проблемы также возникают и у многих учителей, в том числе учителей начальной школы. И если с этническими конфликтами в классе учителям в силу жизненного и педагогического опыта справиться не составляет труда, то проблема обучения инофонов элементарной коммуникации со сверстниками, с учителем, а также проблема освоения ими содержания дисциплин программы, установленной ФГОС РФ, в том числе программы по русскому языку, остается трудно разрешимой. Ребенка из семьи, в которой не говорят на государственном языке страны проживания или слабо им владеют, в данном случае - 
русском, нужно научить не только общаться на бытовые темы, но и подготовить в соответствии с требованиями стандарта начального образования.

Обучающийся обязан осваивать наравне с русскоговорящими детьми образовательную программу, выполнять текущие задания, проверочные и контрольные работы, включая Всероссийские проверочные работы, а в конце обучения в школе сдать Единый государственный экзамен (ЕГЭ) по русскому языку. Задача непростая, как для инофона, так и для учителя начальных классов, ведь дополнительного времени на изучение русского языка программой не предусмотрено, а обращаться к репетитору у родителей зачастую не бывает материальной возможности. Основная нагрузка и ответственность в этом нелегком деле ложится, прежде всего, на плечи учителя. Данная проблема трудно решаемая, она требует активного включения в этот процесс родителей ребенка.

Успешной адаптации детей иностранных граждан к школе способствует взаимодействие учителя начальных классов и их родителей. Именно учитель, понимая значимость взрослого окружения для младшего школьника-иностранного гражданина, способствует выстраиванию вокруг него единой воспитательно-образовательной среды.

Взаимодействие учителя начальных классов с родителями-иностранными гражданами, как правило, не ограничивается традиционными обязательными действиями: оформлением документов ребенка, сбором сведений о школьнике и его семье (анкетирование), присутствием родителей-иностранных граждан на родительских собраниях.

Необходимо отметить, что взаимодействие учителя с родителями-иностранцами может быть осложнено множеством различных трудностей:

- незнание родителями русского языка или слабое владение им;

- опасливое отношение к школе вообще и (или) недоверие к конкретному педагогу (в том числе из-за неудачного предыдущего опыта общения);

- особенности поведения родителей, связанные с национальными, религиозными, семейными традициями и др.

Дополнительного внимания могут потребовать родители первоклассников, если выяснится, что ребенок не готов к школе: психологически (следует порекомендовать немедленно обратиться к школьному психологу), физически - не выполняет элементарные действия по самообслуживанию, не умеет правильно держать в руках письменные принадлежности, рука не готова к письму, пр.

Полиэтничность ученического состава класса предполагает организацию образовательного процесса таким образом, чтобы был задействован весь детский коллектив, включая русскоязычных родителей и родителей-иностранцев. Привлечение родителей (как русско- так и иноязычных) к совместной социокультурной, воспитательной деятельности помогает сплочению коллектива (как детского, так и взрослого), установлению отношений сотрудничества; способствует развитию творческих, интеллектуальных умений детей и взрослых; передаче опыта поколений; установлению благожелательных взаимоотношений в разно-национальном коллективе.

Перечислим некоторые формы взаимодействия в системе «учитель - дети - родители» в полиэтническом классе:

1. Классные часы (как организационного, так и тематического порядка).

2. Проектная деятельность: «Я горжусь своими предками», «Мой родственник участник Великой Отечественной войны», «Ценности нашей семьи» и др.

3. Викторины: «Традиции моего народа»; «Батыр, баятур, богатырь...» (лингвистическая игра на сравнение и отыскивание общего в языковых системах русского и тюркских языков).

4. Мастер-класс от родителей.

5. Выставка совместного творчества детей и родителей. 
6. Природоохранные мероприятия: «Сбережем дерево» (общеклассный или школьный сбор макулатуры), «Посадим дерево у дома», «Пришкольный цветник», субботники.

7. Семейные спортивные состязания: эстафеты, сдача норм ГТО, лыжные гонки, перетягивание каната, игра в шашки, шахматы и др.

8. Украшение классной комнаты к праздникам.

9. Оформление классного уголка, выпуск газеты, плаката и др.

10. Подготовка спектакля (с посильным участием родителей в качестве консультантов, актеров, костюмеров, художников-декораторов, пр.).

11. Фестивали народной песни, национального костюма; конкурсы чтецов, музыкантов, др.

Также можно устраивать выезды на природу или базу отдыха. В процессе неформального общения дети и родители лучше узнают друг друга, много общаются. Учитель совместно с родителями планирует мероприятия с тем, чтобы каждая семья могла представить свою культуру: песни, танцы, конкурсы; спортивные семейные состязания; национальные детские игры - «Дупы ташар» (узб., «Подбрасывание тюбетейки»). Народная узбекская игра «Ок терак, кук терак» («Белый тополь, синий тополь»), например, имеет русский аналог «Цепи кованые», таджикская «Спасение пойманных» («Зиндакунак») очень похожа на русскую подвижную игру «Чай-чай-выручай!», а киргизская «Клади платок» («Жоолух таштамай») - на Зарю-Заряницу.

За обедом (общий обеденный стол всегда сближает) родители могут представить традиционные блюда национальной кухни, заранее приготовленные дома совместно с детьми, и подавать их, например, в национальных костюмах. Угощение может сопровождаться кратким рассказом на русском языке об истории или причинах появления данного блюда в национальной кухне, правилах его подачи и вкушения.

У костра или на вечернем сборе нелишним будет рассказ родителей об обычаях их народа; с особым удовольствием дети слушают легенды, притчи, приключенческие истории из древности.

Некоторые учителя вводят в традицию класса празднование какого-либо национального праздника. На праздник «Наурыз» (Навруз), например, - главный праздник в году у многих народов Азии - детям и их родителям предлагается устроить классное чаепитие. Каждая семья по желанию приносит сладкое национальное угощение.

Как показывает практика, подобного рода мероприятия способствуют как языковому, культурному обогащению участников, так и сплочению коллектива детей и их родителей.

Владение языком страны пребывания для иноэтничного младшего школьника - залог не только успешной коммуникации со сверстниками, учителями, работниками школы, возможность наравне с русскоговорящими одноклассниками осваивать учебные программы, но и условие формирования его межкультурной компетентности и успешной интеграции в российское общество.

Значительные проблемы в знаниях в связи с перерывами в обучении; разница в образовательных программах школьных учреждений настоящего и предыдущего места обучения; неподготовленность к школе; отсутствие, утрата или недостаточность учебных навыков; зачастую низкая учебная мотивация - составляют учебные, психологопедагогические и социально-культурные проблемы детей мигрантов.

К психологическим проблемам, возникающим у иноязычных младших школьников, можно отнести отклоняющееся поведение (тревожность, неуверенность, агрессивность, пассивность, пр.). К социокультурнылм проблемам - незнание иноэтничными младшими школьниками смыслов, ценностей и традиций нового общества, недоверие к новой культуре, низкий социальный статус и материальный достаток семьи, частую смену жительства, др. 
Учебные и социокультурные проблемы младших школьников - детей мигрантов, как мы уже отмечали, в первую очередь, осложняются языковым барьером, слабым знанием русского языка.

Тщательный анализ научной литературы, включая результаты эмпирического исследования, позволили выделить языковые, психологические (социальнопсихологические), социокультурные (социальные и культурные) проблемы иноэтничных детей, обучающихся в русскоязычных школах.

Главным фактором успешной адаптации младшего школьника в иноэтничной среде (стране) является школа. Л.Н. Зимакова рассматривает школьную адаптацию «как совокупный процесс специфической социально-психологической, этнокультурной и учебной адаптации» [8]. «Межкультурная адаптация - целостный многосторонний процесс психологического и социального приспособления к новой культуре, образу жизни и поведению, результатом которого является интеграция в новую культурную среду при сохранении богатств собственной культуры» [22, с. 277, цит. по Зимаковой].

Одна из задач образовательной организации, в том числе учителя начальных классов, - помочь школьнику-иностранцу и его родителям безболезненно «влиться» в новую языковую и культурную среду (постигнуть новые духовно-нравственные ценности), учитывая и сохраняя при этом их религиозные верования и национальную самобытность.

С.А. Дудко по этому поводу пишет: «... учащиеся-мигранты начальной школы овладевают разговорным языком в течение года, иногда меньше. Но даже при успешном освоении разговорного языка обычно остаются серьезные пробелы в письменной речи, что требует специальных дополнительных занятий» [4, с. 4].

Иноэтничный ребенок, как и любой другой младший школьник, поступая в школу, приобретает новый социальный статус, возникают новые отношения со сверстниками, со взрослыми (учителями), учебная деятельность становится для него ведущей. В начальной школе главная задача обучающегося - приобрести умение учиться. Иноязычный младший школьник учится постигать новое в науках, проникать в суть вещей и явлений, учится анализировать, экспериментировать, делать выводы - осваивать главное, что станет впоследствии основой его профессии и жизни.

Достаточно острая проблема для иноэтничных первоклассников - неготовность к школе. Отмечается психологическая неготовность: рассеянность внимания, неусидчивость, быстрая утомляемость, тревожность, конфликтность/замкнутость, неумение управлять своими поступками и др. Нередко дети мигрантов не готовы к обучению в школе интеллектуально: выявляется неспособность к анализу, обобщению, выводам, неумение устанавливать причинно-следственные связи между явлениями действительности, недостаточный запас знаний об окружающем мире и др.

Социально-личностная неготовность проявляется в неумении общаться со сверстниками, взрослыми; у иноэтничных младших школьников наблюдается заниженная/завышенная самооценка, нежелание/неумение выполнять требования учителя и др. Отсутствие мотивационной готовности к обучению проявляется нежеланием познавать новое.

Большей частью все перечисленные проблемы иноэтничных младших школьников возникают в связи с тем, что они до начала обучения не посещали дошкольное учреждение или включились в учебный процесс на принимающей территории позже установленного срока. Кроме того, они сменили привычное место жительства и, находясь в отличной от привычной им языковой, культурной среде, чувствуют себя некомфортно. Отсутствие помощи родителей в силу незнания ими русского языка и (или) зачастую недостаточного уровня образованности - также важный фактор наличия учебных проблем детей мигрантов.

Анализ изложенных результатов. Таким образом, можно резюмировать: адаптированность является фундаментом, условием для раскрытия способностей человека, 
его самопроявления, развития. «Она не определяет ни направленности, ни интенсивности его в самопроявлении. Ребенок может чувствовать себя комфортно, но при этом не проявлять необходимой конструктивной активности. Важно не только способствовать адаптации ребенка, но и содействовать проявлению его направленной активности в учебе, досуговой деятельности, в самосовершенствовании» [18, с. 124].

«Социальная адаптированность, - пишет Л.В. Мардахаев, - состояние, наиболее благоприятное для социализации человека при проявлении целесообразной активности. Особое значение имеет социальная адаптация ребенка - процесс согласования индивидуальных возможностей и состояния ребенка с окружающим миром, приспособление его к изменившейся среде, новым условиям жизнедеятельности, структуре отношений в общностях, установления соответствия поведения принятым в них нормам и правилам» [18, c. 124].

Заключение и выводы. Результаты проведенного исследования позволяют сделать следующее заключение: социальная адаптированность ребенка из семьи мигрантов выступает необходимым условием для его полного самопроявления в окружающей его новой социокультурной среде, что оказывает позитивное влияние на процесс его социализации и дальнейшей успешной интеграции в российское общество. Полученные результаты позволяют сделать следующие выводы:

1. Единого универсального определения сущности понятий «адаптация мигрантов», «социализация мигрантов», «интеграция мигрантов», в том числе касающихся иноэтничных младших школьников, в зарубежной и отечественной литературе, правовых документах Российской Федерации на данный момент не выработано.

2. На сегодняшний день у иноэтничных младших школьников существует целый комплекс проблем, связанный с их адаптацией к русскоязычной школе: языковая, психологическая, социокультурная, учебная, др., что, соответственно требует их эффективного решения (помощь, поддержка, сопровождение) как детям с особыми образовательными потребностями.

3. Главным условием социокультурной, психологической и др. адаптации иноязычного ребенка младшего школьного возраста на территории Российской Федерации является комфортная для него воспитательная социокультурная среда школы.

Результаты анализа научных публикаций, эмпирических исследований показывают, что проблема социальной адаптации детей мигрантов к новой для них школьной среде, с одной стороны - сложная и противоречивая, с другой - вполне решаемая и требуемая комплексного подхода при обязательном согласовании действий всех участников образовательного процесса: родителей-мигрантов и их детей, педагогического коллектива школы, других заинтересованных лиц и организаций.

\section{Литература:}

1. Боярский П.В. Положение и права мигрантов в сфере школьного образования в России // Молодой ученый. - 2020. - № 20 (310). - С. 247-253.

2. Гукаленко О.В., Бондаревская Е.В. Педагогические основы межкультурного общения: учебное пособие. - Тирасполь: Изд-во: Ростовский государственный педагогический университет, 2000. - 80 c. URL: https://elibrary.ru/item.asp?id=35364166

3. Деминцева Е.Б. Дети мигрантов в школах Томска и Иркутска: проблемы адаптации и меры включения в школьное пространство // Журнал исследований социальной политики. - 2020. - Т. 18, № 4. - C. 673-688. DOI: https://doi.org/10.17323/727-0634-2020-18-4673-688

4. Дудко С.А. О современных проблемах обучения детей мигрантов русскому языку // Школьные технологии. - 2016. - № $3 . \quad$ - C. 3-6. URL: https://elibrary.ru/item.asp?id=26747449 
5. Засыпкин В.П., Зборовский Г.Е., Шуклина Е.А. Актуальные проблемы обучения детей мигрантов // Вестник Сургутского государственного педагогического университета. - 2012. - № 2 (17). - C. 9-36. URL: https://elibrary.ru/item.asp?id=17774749

6. Засыпкин В.П., Зборовский Г.Е., Шуклина Е.А. Обучение детей мигрантов как социально-педагогическая проблема // Педагогический журнал Башкортостана. - 2013. - № 2 (45). - C. 35-51. URL: https://elibrary.ru/item.asp?id=20210295

7. Зборовский Г.Е., Шуклина Е.А. Обучение детей мигрантов как проблема их социальной адаптации // Социологические исследования. - 2013. - № 2 (346). - C. 80-91. URL: https://elibrary.ru/item.asp?id=18863684

8. Зимакова Л.Н. Модель психолого-педагогического сопровождения школьной адаптации детей-мигрантов (на начальном этапе обучения) // Гуманитарные, социальноэкономические и общественные науки. - 2014. - №8. - C. 195-198. URL: https://elibrary.ru/item.asp?id=21971488

9. Зинченко Е.Ю., Хазов Е.Н., Евсеева И.Г., Никитский М.В. Особенности правового положения несовершеннолетних мигрантов в России // Вестник экономической безопасности. - 2019. - № 4. - C. 30-35. URL: https://www.elibrary.ru/item.asp?id=42477759

10. Иванова Г.П., Стецевич М.Ю., Ширкова Н.Н. Проблема адаптации детеймигрантов в образовательном учреждении: результаты теоретического и эмпирического исследования // Социальные отношения. 2018. Т. 25. - № 2. - С. 106-115. URL: https://www.elibrary.ru/item.asp?id=35090354

11. Кириченко С.Н. Этнокультурный диалог в образовательном процессе // Дополнительное образование. - 2002. - № 3. - С. 32-40.

12. Кононов Л.А., Леденева В.Ю. Адаптация и интеграция международных мигрантов: теоретико-методологические проблемы // Мировая экономика и международные отношения. - 2021. - Т. 65, № 4. - C. 103-112. URL: https://doi.org/10.20542/0131-2227-2021-654-103-112

13. Константинов В.В. Социально-психологические характеристики адаптации мигрантов в современных условиях: монография. - Пенза: ПГПУ им. В.Г. Белинского, 2007. 187 c. URL: https://www.elibrary.ru/item.asp?id=20091806

14. Кукушин В.С. Воспитание толерантной личности в поликультурном социуме: учебное пособие. - Ростов-на Дону: ГинГо, 2002. - 404 с.

15. Куприна Т.В. Обучение детей мигрантов в школах России: проблемы и пути их решения // Многоязычие в образовательном пространстве. - 2017. - № 9. - С. 65-74. URL: https://elibrary.ru/item.asp?id=32542799

16. Леденева В.Ю., Кононов Л.А. Государственное и муниципальное регулирование процессов адаптации и интеграции мигрантов в современной России: монография. - Москва: РУДН, 2021. - 296 с. URL: https://elibrary.ru/item.asp?id=44723833

17. Макаров А.Я. Особенности этнокультурной адаптации детей мигрантов в московских школах // Социологические исследования. - 2010. - № 8 (316). - C. 94-101. URL: https://elibrary.ru/item.asp?id=15138239

18. Мардахаев Л.В. Адаптация и дизадаптация человека: социальнопедагогический аспект (лекция) // Вопросы психического здоровья детей и подростков. 2016. - T.16, № 2. - C. 122-131. URL: https://elibrary.ru/item.asp?id=26620829

19. Омельченко Е.А. Адаптация и интеграция иноэтничных мигрантов: проблема определения понятий в современных исследованиях // Современное образование: векторы развития. Инновационные подходы к преподаванию социально-гуманитарных дисциплин: матер. IV Международной конф. / под общей ред. М.М. Мусарского, Е.А. Омельченко, А.А. Шевцовой. - М.: МПГУ, 2019. - С. 259-274. URL: https://elibrary.ru/item.asp?id=41229909

20. Омельченко Е.А. Социально-культурная адаптация детей из семей мигрантов в школе: методика исследования и пути решения проблемы // Человек в меняющемся мире. 
Проблемы идентичности и социальной адаптации в истории и современности: сборник научных статей. - Томск: Изд-во: НИТГУ, 2015. - C. 249-260. URL: https://elibrary.ru/item.asp?id=25891612

21. Рязанцев С.В., Леденева В.Ю. Интеграция иммигрантов в условиях этнодемографических трансформаций регионов России // Вопросы национальных и федеративных отношений. - 2020. - T. 10, № 12(69). - C. 2850-2858. URL: https://elibrary.ru/item.asp?id=44483662

22. Стефаненко Т.Г. Этнопсихология. - М.: Институт психологии РАН, «Академический проект», 1999. - 320 с. ISBN 5-201-02323-1

23. Суровцова Е.И. Социально-педагогическое сопровождение детей-мигрантов в школе // Педагогическое образование в России. - 2014. - № 12. - С. 184-188. URL: https://elibrary.ru/item.asp?id=23460825

24. Солдатова Г.У. Психология межэтнической напряженности // Социальные и гуманитарные науки. Отечественная и зарубежная литература. серия 5: История. реферативный журнал. - 1999. - № 1. - С. 153-155.

25. Суслова Т.Ф., Комарова Н.М., Грибкова С.В. Оценка этнокультурной адаптации детей из семей мигрантов специалистами социальных организаций // Вестник Московского государственного областного университета. Серия: Психологические науки. 2019. - № 1. - C. 50-65. DOI: 10.18384/2310-7235-2019-1-50-65

26. Тесленко В.И. Тржебятовская Н.М. Проблемы обучения детей-мигрантов в современной российской школе // Вестник Красноярского государственного педагогического университета им. В.П. Астафьева. - 2018. - № 4 (46). - С. 6-14. URL: https://elibrary.ru/item.asp?id=36634884

\section{References:}

1. Boyarsky P.V. The position and rights of migrants in the field of school education in Russia. Young scientist, 2020, no. 20 (310), pp. 247-253. (In Russian)

2. Gukalenko O.V., Bondarevskaya E.V. Pedagogical foundations of intercultural communication: a tutorial. Tiraspol, Rostov State Pedagogical University Publ., 2000. 80 p. (In Russian) URL: https://elibrary.ru/item.asp?id=35364166

3. Demintseva E.B. Children of migrants in schools of Tomsk and Irkutsk: problems of adaptation and measures of inclusion in the school space. Journal of Social Policy Research, 2020, vol. 18, no. 4, pp. 673-688. (In Russian) DOI: https://doi.org/10.17323/727-0634-2020-18-4-673$\underline{688}$

4. Dudko S.A. About modern problems of teaching Russian language to children of migrants. School technologies, 2016, no. 3, pp. 3-6. (In Russian) URL: https://elibrary.ru/item.asp?id=26747449

5. Zasypkin V.P., Zborovsky G.E., Shuklina E.A. Actual problems of teaching children of migrants. Bulletin of the Surgut State Pedagogical University, 2012, no. 2 (17), pp. 9-36. (In Russian) URL: https://elibrary.ru/item.asp?id=17774749

6. Zasypkin V.P., Zborovskiy G.E., Shuklina E.A. Teaching children of migrants as a social and pedagogical problem. Pedagogical journal of Bashkortostan, 2013, no. 2 (45), pp.. 3551. (In Russian) URL: https://elibrary.ru/item.asp?id=20210295

7. Zborovsky G.E., Shuklina E.A. Teaching children of migrants as a problem of their social adaptation. Sociological research, 2013, no. 2 (346), pp. 80-91. (In Russian) URL: https://elibrary.ru/item.asp?id=18863684

8. Zimakova L.N. Model of psychological and pedagogical support of school adaptation of migrant children (at the initial stage of education). Humanitarian, socio-economic and social sciences, 2014, no. 8, pp. 195-198. (In Russian) URL: https://elibrary.ru/item.asp?id=21971488 
9. Zinchenko E.Yu., Khazov E.N., Evseeva I.G., Nikitsky M.V. Features of the legal status of underage migrants in Russia. Bulletin of economic security, 2019, no. 4, pp.. 30-35. (In Russian) URL: https://www.elibrary.ru/item.asp?id=42477759

10. Ivanova G.P., Stetsevich M.Yu., Shirkova N.N. The problem of adaptation of migrant children in an educational institution: the results of theoretical and empirical research. Social relations, 2018, vol. 25, no. 2, pp. 106-115. (In Russian) URL: https://www.elibrary.ru/item.asp?id=35090354

11. Kirichenko S.N. Ethnocultural dialogue in the educational process. Additional education, 2002, no. 3, pp. 32-40. (In Russian)

12. Kononov L.A., Ledeneva V.Yu. Adaptation and integration of international migrants: theoretical and methodological problems. World Economy and International Relations, 2021, vol. 65, no. 4, pp. 103-112. (In Russian) URL: https://doi.org/10.20542/0131-2227-2021-654-103-112

13. Konstantinov V.V. Socio-psychological characteristics of adaptation of migrants in modern conditions. Monograph. Penza, PSPU im. V.G. Belinsky Publ., 2007. 187 p. (In Russian) URL: https://www.elibrary.ru/item.asp?id=20091806

14. Kukushin V.S. Education of a tolerant personality in a multicultural society. Rostovon-Don, GuinGo Publ., 2002. 404 p. (In Russian) URL: https://elibrary.ru/item.asp?id=32542799

15. Kuprina T.V. Teaching migrant children in Russian schools: problems and ways to solve them. Multilingualism in the educational space, 2017, no, pp. 65-74. (In Russian) URL: https://elibrary.ru/item.asp?id=32542799

16. Ledeneva V.Yu., Kononov L.A. State and municipal regulation of the processes of adaptation and integration of migrants in modern Russia. Monograph. Moscow, RUDN Publ., 2021, 296 p. (In Russian) URL: https://elibrary.ru/item.asp?id=44723833

17. Makarov A.Ya. Features of ethnocultural adaptation of migrant children in Moscow schools. Sociological studies, 2010, no. 8 (316), pp. 94 - 101. (In Russian) URL: https://elibrary.ru/item.asp?id=15138239

18. Mardakhaev L.V. Human adaptation and inadaptation: social and pedagogical aspect (lecture). Questions of mental health of children and adolescents, 2016, vol. 16, no. 2. pp. 122-131. (In Russian) URL: https://elibrary.ru/item.asp?id=26620829

19. Omelchenko E.A. Adaptation and integration of foreign ethnic migrants: the problem of definition of concepts in modern research. Moscow, Moscow State Pedagogical University Publ., 2019. pp. 259-274. (In Russian) URL: https://elibrary.ru/item.asp?id=41229909

20. Omelchenko E.A. Social and Cultural Adaptation of Children from Migrant Families at School: Research Methods and Ways to Solve the Problem. Tomsk, NITGU Publ., 2015. pp. 249-260. (In Russian) URL: https://elibrary.ru/item.asp?id=25891612

21. Ryazantsev S.V., Ledeneva V.Yu. Integration of immigrants in the context of ethnodemographic transformations of Russian regions. Issues of national and federal relations, 2020, vol. 10, no. 12 (69), pp. 2850-2858. (In Russian) URL: https://elibrary.ru/item.asp?id=44483662

22. Stefanenko T.G. Ethnopsychology. Moscow, Institute of Psychology RAS, "Academic project" Publ., 1999. 320 p. (In Russian) ISBN 5-201-02323-1

23. Surovtsova E.I. Socio-pedagogical support of migrant children at school. Pedagogical education in Russia, 2014, no. 12, pp. 184-188. (In Russian) URL: https://elibrary.ru/item.asp?id=23460825

24. Soldatova G.U. Psychology of interethnic tension. Social and humanitarian sciences. Domestic and foreign literature. Episode 5: History. abstract journal, 1999, no. 1, pp. 153-155. (In Russian)

25. Suslova T.F., Komarova N.M., Gribkova S.V. Assessment of ethnocultural adaptation of children from migrant families by specialists of social organizations. Bulletin of the 
Moscow State Regional University. Series: Psychological Sciences, 2019, no. 1, pp. 50-65. (In Russian) DOI: 10.18384/2310-7235-2019-1-50-65

26. Teslenko V.I. Trebyatovskaya N.M. Problems of teaching children-migrants in the modern Russian school. Bulletin of the Krasnoyarsk State Pedagogical University. V.P. Astafieva, 2018, no. 4 (46), pp. 6-14. (In Russian) URL: https://elibrary.ru/item.asp?id=36634884

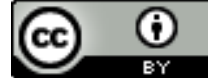

